\title{
Making an Antislavery Nation: Lincoln, Douglas, and the Battle over Freedom
}

Review Number: 2251

Publish date: Thursday, 7 June, 2018

Author: Graham A. Peck

ISBN: 978-0252041365

Date of Publication: 2017

Price: $£ 26.99$

Pages: 280pp.

Publisher: University of Illinois Press

Publisher url: https://www.press.uillinois.edu/books/catalog/86qfb7km9780252041365.html

Place of Publication: Champaign

Reviewer: John Craig Hammond

While campaigning for the Senate in 1858, Abraham Lincoln delivered one of his most enduring speeches. Reflecting on the previous half-decade's sectional struggles, Lincoln predicted that the nation's conflict over slavery 'will not cease, until a crisis shall have been reached, and passed'. Citing a familiar Biblical metaphor, Lincoln added, 'A house divided against itself cannot stand. I believe this government cannot endure, permanently half slave and half free. I do not expect the Union to be dissolved - I do not expect the house to fall - but I do expect it will cease to be divided. It will become all one thing or all the other'. How that crisis came to pass, and why it took the form that it did, is a perennial historical and historiographical question. Graham A. Peck ably addresses it by focusing on the state of Illinois and two of the era's most prominent politicians in Making an Antislavery Nation: Lincoln, Douglas, and the Battle over Freedom.

Written as a traditional political narrative, Making an Antislavery Nation is grounded in that genre's primary sources. Congressional speeches, the correspondence of elite politicians, and articles from the partisan press fill the endnotes. Likewise, Peck relies heavily on traditional secondary sources; many are nearing a halfcentury old, more than a few are over a century old. The book's topics also focus on political history's traditional concerns with ideological changes, shifting partisan alignments, backroom negotiations, personal political ambitions, fluctuating alliances, the passage of bills in state houses and Congress, and party platforms. Women and Native Americans are wholly absent from the book; African-Americans make only brief appearances. Its methodology is conventional, and its contents are largely familiar to specialists in antebellum and Civil War United States history. Peck is hardly the first to write about Abraham Lincoln and Stephen Douglas, slavery and the Civil War; he will not be the last. It is difficult to say something novel and worthwhile while moving through such well-trodden ground. So how does Peck's account differ from the many that have come before him? What prevents this from becoming just another book about Lincoln, Douglas, and the twisting road to the Civil War?

Peck's main contention is that 'profound and persistent conflict between slavery and freedom convinced a majority of Northerners by the 1850s that the nation's commitment to the ideals and practices of freedom was imperiled' (p. 2). For both northern and southern whites, freedom 'conjoined personal independence most notably economic opportunity, religious liberty, political equality, and individual rights - to a national 
mission promoting the social, spiritual, and material progress that flowed from free institutions' (p. 4). For northern whites, slaves and slaveholders stood as the main threat to northern whites' notions of freedom and the institutions that embodied them. From the 1810s through the 1850 s, many white northern voters and politicians became convinced that the nation's commitment to freedom could advance only in the absence of slavery and slaveholders. By 1860, Republican voters and politicians identified slaveholders and the overtly pro-slavery Democratic Party as the chief threat to their cherished notions of freedom, nation, and progress. Conversely, for southern whites, black slavery served as the foundation of white, male freedom. For them, the nation's mission could advance only when government protected slavery and the rights of slaveholders. Much of the monograph is devoted to examining the developing meanings and practices of freedom, the ideologies of nationalism within which they were embedded, the partisan and sectional conflicts that created them, and the ways in which they increasingly came into conflict with one another.

Making an Antislavery Nation is also notable for its chronological scope. Peck begins his analysis in the 1810 s, at times reaching back to the 1780s. Despite some notable exceptions, antebellum historians have largely overlooked the periods prior to Texas Annexation and the U.S.-Mexico War in the 1840s. In turn, too many interpretations of the events and divisions that led to disunion are myopic and short-sighted. In contrast, Peck claims that 'the slavery crisis was rooted so deeply in the nation's past, and so intertwined with slaveholders' social, economic, and political power, that it kept springing back to life despite a never ending series of compromises or other initiatives designed to end the strife' (p. 11). Peck analyzes those conflicts and compromises, starting with the the Constitutional Convention of 1787, moving through to the controversy over legalizing slavery in Illinois in the early statehood period, and concluding with the twisted path that stretched from the U.S.-Mexico War to the election of 1860. In doing so, Peck lends credence to his contention that, at base, sectional conflict rested on competing ideologies of freedom and nationalism. He also demonstrates that conflicts over slavery were foundational and inevitable, so long as Southern whites refused to give up slavery, and so long as northern whites refused to reject the principles of the Declaration of Independence. Focusing on both 'long-term, deeply rooted antagonisms' and 'short-term contingent decisions by individuals' (p. 5), Peck explores how parties and politicians contained those antagonisms in Illinois and the United States, and how they erupted into conflict in the 1850s.

The first half of the book charts the vicissitudes of pro-slavery and anti-slavery advocates in Illinois from the 1810s through the early 1850s. Along the way, Peck examines how political parties, including the Whigs and the Democrats, the Liberty Party and the Free Soil Party, contributed to the matrix of principles, practices, and institutions on which Lincoln's anti-slavery nationalism would rest. Peck also examines how a host of issues - including disputes over everything from government funding for canals to the state chartering of banks to the annexation of Texas and the Pacific Northwest - shaped the ideologies and political practices of parties and voters, contributing to southern and northern notions of freedom. 
Peck's focus on Illinois works well. Stretching from the Great Lakes along the northern tier of the state to the Ohio Valley in the state's southern half, Illinois was divided by slavery and sectional differences from its inception as a territory. Slavery had existed in the Illinois Country from its time as a French colony in the early 1700s. Though the Northwest Ordinance of 1787 banned slavery in Illinois, the institution continued to grow through the 1810s due to a series of loopholes and evasions. In 1818 and again in 1824, slaveholders sought to overturn the Northwest Ordinance's ban on slavery, thus fully legalizing the institution in the state. Anti-slavery forces managed to organize politically and defeat efforts to legalize slavery in the early statehood period. Otherwise, anti-slavery sentiments failed to crystalize into an anti-slavery ideology, and anti-slavery movements failed to cohere into effective anti-slavery political parties until 1854 . With the issue of slavery's future in Illinois settled in 1824, questions about economic development, democracy, and freedom became decoupled from the slavery question. Democrats and Whigs sought federal funding for river improvements along the Mississippi, harbor improvements in the booming port of Chicago, and a canal linking the Great Lakes with the Mississippi River. In addition, Democrats in both northern and southern Illinois supported Manifest Destiny's demand for Texas Annexation and US occupation of the Pacific Northwest. Texas would provide markets for the agricultural surplus produced by Illinois farmers while the Oregon Country would provide farms for those seeking to settle elsewhere.

Party loyalties ran deep in Illinois, and Whigs and Democrats elevated partisan loyalties above section and sentiment for the better part of 30 years. Furthermore, slavery and sectionalism rarely entered directly into political conflicts over banks and canals, or even expansion. Nonetheless, according to Peck these issues were important to developing conflicts over slavery and nationalism. In these chapters, Peck traces the ways that Whig and Democratic policies and ideologies forged notions of freedom and nationalism among Illinois's voters and politicians. Both parties cloaked their regional interests and party policies in terms of the national interest and personal freedom, laying the foundation for the later development of an anti-slavery nationalism.

The second half of the book follows the standard chronology and series of events that moves from the Kansas-Nebraska Act to the election of Lincoln. Over the course of these chapters, Peck moves rather effortlessly between a host of issues (from Nativism and temperance to landgrants and railroads); a plethora of parties and factions (Anti-Nebraskites, Americans, and Free Democrats), and a range of regions in both Illinois and the United States (northern, southern, and Central Illinois; the lower North and the Northeast). These chapters are not for the uninitiated, and Peck assumes a certain level of background knowledge on the reader's part. For those with the requisite background, Making an Antislavery Nation is at its best when it traces the forces that led to the collapse of Democrats in Illinois and across the North, and the corresponding creation of a unifying, anti-slavery nationalist ideology by Lincoln.

The Compromise of 1850 temporarily smoothed over matters for Whigs and Democrats in Illinois. Both parties denounced efforts to reopen the slavery question and professed their commitment to preserving the Compromise and Union. In terms of policy positions on non-slavery issues, the differences between the two parties narrowed. Both parties supported homesteads, railroad grants, and river and harbor improvements. On economic matters, most Illinois Democrats endorsed formerly Whig positions on corporations, wage labor, and state funding for transportation improvements. With the old issues on both slavery and economic development seemingly solved, voter participation declined and partisan identification withered. At the same time, the northern tier of the state boomed while completion of the Illinois-Michigan Canal saw Chicago emerge as the hub of commerce for the Upper Midwest. The boost in commerce, along with the processing of the commodities of the land - everything from corn and wheat to meat, hides, and lumber - created a rapidly growing class of propertyless wage laborers in Chicago and propertyless farm laborers in rural areas. To solve the problem of a growing class of seemingly permanent wage laborers, most white Illinoisans advocated for land reform over unionization or socialism. As Peck notes, 'proposals to confront the nation's labor problem were more likely to emphasize anti-slavery than anticapitalism' (p. 111). The temporary elevation of nativism and temperance to important political issues further eroded partisan identification. By 1853, Douglas needed a national issue to rally the Democratic Party and differentiate it from the Whigs. He 
found it in the Great Plains. Douglas's Democratic Party would organize territorial governments, sell land cheaply or give it away to farmers, and use land grants to build a transcontinental railroad.

Peck necessarily enters into a long-standing historiographical dispute concerning Douglas's motives for opening the Great Plains to slavery through popular sovereignty, the practice where settlers in a territory would determine whether or not slavery would be permitted. Dismissing conventional wisdom which holds that Douglas endorsed popular sovereignty under pressure from southern Democrats, Peck contends that Douglas was a true believer in popular sovereignty and supported it for his own principled and political reasons. Douglas believed that popular sovereignty upheld the principles and practices of self-government. Douglas also sought to enshrine popular sovereignty into a place of constitutional principle and precedent, thus eliminating future conflicts over slavery's expansion. He hoped that delivering a crushing defeat to antislavery Democrats would destroy the anti-slavery partisans who he contended artificially enflamed northern passions. Finally, Douglas was a moral supporter of slavery, even if he contended that northerners were free to exclude it from their own states and territories. Douglas also supported slavery on political and economic grounds: slavery thrived in sub-tropical regions of the United States that produced cash-crops but seemed redundant in staple producing and manufacturing states in the North. Slavery in the South and its absence in the North created a diverse but thriving economy in the United States. Peck's emphasis on the agency of Northern Democrats in pursuing their own agenda in the 1850s further differentiates this work from others, which tend to focus on southern radicals and northern abolitionists in explaining the rise in sectional tensions in the $1850 \mathrm{~s}$.

Douglas badly underestimated the depth and breadth of northern opposition to opening Kansas to slavery. Northerners accepted popular sovereignty in 1850 as a temporary expedient - not as a constitutional or political principle. Its only purpose was to head off an immediate crisis over slavery in the Mexican Cession. When Douglas sought to use popular sovereignty to organize the Kansas and Nebraska territories in 1854, it appeared to be a blatantly pro-slavery attempt to overturn the Missouri Compromise. Southern machinations worsened the situation for Douglas. Rather than allowing popular sovereignty to determine slavery's fate in Kansas, southerners and Democrats shamelessly used fraud and violence to force slavery on Kansas, a place where very few settlers actually wished to establish it. The Dred Scott Decision, the pro-slavery Lecompton Constitution, and southern demands for a federal slave code for the territories only made matters worse for northern Democrats. Douglas nonetheless made support for popular sovereignty a test of party loyalty. To pass that test, northern Democrats had to defend slavery and the grossly anti-democratic actions of southern slaveholders.

Southern demands led Douglas to embrace increasingly untenable positions on slavery's expansion. Furthermore, in his efforts to reconcile differences between northern and southern Democrats, he only managed to alienate both. Pro-slavery popular sovereignty went too far for northern whites, but not nearly far enough for southern politicians. Douglas found himself tasked with the impossible: reconciling northern voters to the strident demands of southern politicians. Southern politicians cared little about democracy, the rights of majorities, or popular sovereignty by the 1850s. All that seemingly interested them was using the powers of the federal government to protect and promote their rights and interests. Douglas's refusal to endorse southern demands for a territorial slave code cost him the regular Democratic nomination in 1860. But, Douglas's endorsement of pro-slavery ideologies went too far with northerners who accepted the enslavement of blacks, in practice, as a temporary measure, but rejected ideologies which elevated the enslavement of blacks to a sacred, divine, and national mission, thus perpetuating it. Northern whites who could not give themselves over to openly defending slavery had to oppose it. Douglas and the Democratic party made northern whites choose between slavery and freedom, driving once loyal partisans to flee the party.

The Republican Party offered them a welcome home. Lincoln's anti-slavery nationalism would provide the disparate groups who found themselves partyless with a degree of ideological coherence. But before then, anti-slavery voters and partisans faced numerous obstacles in turning their opposition to slavery's expansion into a coherent party. Initially, all that united Anti-Nebraskites was their opposition to the Kansas-Nebraska 
Act. Whigs and Free Democrats in Central Illinois were wary of aligning with real and imagined radical abolitionists. Old partisan and ethnic suspicions stymied attempts at 'fusion': Whigs and Democrats distrusted one another, and both were wary of Republicans. Likewise, free soil Irish and German voters were wary of Whigs and Nativists, and the feelings were mutual. Despite these differences and suspicions, 'the anti-Nebraskites did share a common devotion to the national idea of freedom' (p. 159). Abraham Lincoln, more than any other individual, emerged as the lead author of an ideologically potent form of anti-slavery nationalism that would draw together the motley collection of partisans, ethnic groups, and regions into a political party capable of winning state and national elections.

Lincoln forged a simple creed and set of policies that appealed to voters from across the anti-slavery and free soil spectrum; everyone from avowed negrophobes to racial egalitarians could agree that slavery's expansion had to be halted. Lincoln's anti-slavery nationalism held that the Declaration of Independence, the Constitution, and the founders established freedom as the national standard and slavery as a local exception. The anti-slavery nationalism fixed in the notion of 'freedom national' invited voters and partisans to imagine an anti-slavery past that stretched back to the founders, the Declaration of Independence, and the Constitution. To reject anti-slavery nationalism was to reject the founders and the Revolution. Lincoln portrayed the founders as devotees of freedom who accepted slavery's continuation where it already existed only as a matter of expediency, not principle. In principle if not always in practice, Lincoln's founders were committed anti-slavery nationalists. When Douglas attacked Lincoln as a radical, especially during the Lincoln-Douglas debates - it only sharpened Lincoln's efforts to paint the Republicans as conservatives who were upholding the legacy of the Revolution while casting pro-slavery politicians as radicals advocating for a sharp break from the nation's founding principles.

Lincoln also grounded his anti-slavery nationalism in a celebration of the North's peculiar notions and practices of 'freedom.' In Lincoln's anti-slavery nationalism, 'freedom' denoted the idealized northern order of equal opportunity to advance, property ownership, political equality, and democratic self-government. By 1860, southern slaveholders and Douglas's Democratic Party stood as the chief threat to the North's cherished notions of freedom and nation, along with the material conditions that underwrote it - large quantities of cheap land free of both slaves and slaveholders. Lincoln's nomination followed directly from his work in forging a cohesive ideological creed for the Republicans. Heading into the all-important election of 1860, the Republicans needed a candidate 'to unify a discordant mix of radicals, moderates, conservatives, immigrants, and nativists in a manner appealing to voters in the crucial Lower North states' (p. 178). Who could serve that role better than the primary author of the Republicans' anti-slavery nationalism?

Making an Antislavery Nation elucidates overlooked or underemphasized dimensions of the shifting set of beliefs about freedom and slavery that cohered into Lincoln's ideological vision of an anti-slavery nation. Peck's notion of anti-slavery nationalism also goes far in explaining why so many northerners rejected the Democratic Party in 1860, voted Republican, and then went to war over secession. For northern anti-slavery nationalists who filled the ranks of the Republican Party, the Democrats overtly pro-slavery platform could only be understood as a fundamental betrayal of the Revolution, a direct affront to the nation's founding principles, and the chief threat to the practices of freedom and democratic self-government idealized in the North. Lincoln's anti-slavery nationalism made disunion in support of perpetual slavery heterodoxy. Graham Peck effectively reminds us where that anti-slavery nationalism came from.

Graham Peck appreciates this review and thanks John Craig Hammond for his work reviewing it.

\section{Other reviews:}

New York Review of Books

http://www.nybooks.com/articles/2007/03/29/what-did-he-really-think-about-race/ [2]

Source URL:https://reviews.history.ac.uk/review/2251

\section{Links}

[1] https://reviews.history.ac.uk/item/296353 
[2] http://www.nybooks.com/articles/2007/03/29/what-did-he-really-think-about-race/ 